\title{
Impact of Self-Service Factors on Customer Value: How Customer Behavioral Intentions are Formed?
}

The service industry, particularly the self-service, is considered as more important for service innovation while economy continues to develop. With information, communication and advances in network technology, the service model of the traditional service industry must be changed into three aspects: scientific, technological progress, and competitive environment to create business value by consumer expectation (Trivedi et al., 2018). Due to the advancement of service and information technologies, self-service services are not only divided in various categories, but also integrated into people's daily life and work today. It is imperative for service industry practitioners to exactly understand the factors determining the self-service model to strengthen their competitive advantage. More self-service styles are applied in human living and work resulted due to the advancement of service and information technologies (Bailey et al., 2017; Chiu et al., 2017). For example, online banking transfers, placing orders, purchasing funds, automated teller machine (ATM) funds deposit and withdrawal (Mukerjee, 2020; Kimes and Collier, 2015), expressway electronic toll collection (ETC), public and private parking lot by automatic payment machines, MRT stations' automated ticketing machines, self-service gas stations, price checking machines in mass merchandise stores and super- 
markets, etc.

The technology acceptance model (TAM) suggests that self-service usage is driven by perceived usefulness and perceived ease of use (Bailey et al., 2017; Abdullah and Ward, 2016; Davis, 1989). Studies have shown that perceived usefulness and perceived ease of use influence the behavioral intentions of customers (Dwivedi et al., 2019). For instance, Meuter et al. (2000) believe that whether consumers decide to try self-service depends on their readiness, including ability, role clarity and motivation. Dabholkar and Bagozzi (2002) used the general attitude towards the use of technology based on self-service as the intermediary variable. Meuter et al. (2003) used consumer readiness as an intermediary variable. However, few studies have explored customer value as a key intermediary variable to explore customer acceptance or purchase intentions and its influencing factors in a selfservice context is the only exception (Chen et al., 2018; Collier and Sherrell, 2010).

Self-service have made service delivery for customers cost-effective, convenient, and ubiquitous (Wirtz and Zeithaml, 2018). In modern marketing concepts, especially from the viewpoints of relationship marketing and performance marketing, customer value is regarded as a key influencing factor of customer loyalty (Trivedi et al., 2018). Therefore, it is worthy to explore the mediating role of customer value. Literature shows that previous research mostly focused on the factors of self-service "technology" itself, such as ease of use and usefulness (Davis, 1989), innovative features (Meuter et al., 2000), speed and reliability (Shamdasani et al., 2008), convenience (Collier and Sherrell, 2010; Globerson and Maggard, 1991). In addition, few dealing with the adoption buying-decisions process of self-service explored consumer or user level factors (Chen et al., 2018; Chen and Wang, 2016; Dabholkar and Bagozzi, 2002). Consequently, the behavioral intentions of customers' need further research (Giebelhausen et al., 2014; Robertson et al., 2016).

The mandatory use of self-service by some service providers and the enhanced e-service quality have led to loyalty among self-service users (Reinders et al., 2015; Theodosiou et al., 2019). Businesses require technological development to enhance service value and profit, with an even more competitive service pattern of innovation for delivery and creating higher customer value. The accelerating growth in technology-based self-service that is giving the acceptance of such forms of service delivery by all kinds of consumers and under different situational contexts (Dabholkar et al., 2002). In view of above background development, the purpose of this research is to examine the influence of self-service on customer behavioral intentions. This study also attempts to examine the mediating roles of customer value for the aforementioned relationships.

\section{LITERATURE REVIEW}




\section{Theoretical Underpinnings}

Resource matching theory (RMT) is used to explain how to optimize the user's cognitive resources to complete tasks (Anand and Sternthal, 1990). This theory assumes that consumer's cognitive resources are limited. When the user's mental elaboration of cognitive resources and tasks are matched, we can have the best results. More or less, user's cognitive resources than the required task, the user's decision performance will be affected. Research showed that using the self-service can bring many benefits (Meuter et al., 2003), for example, effective processing to complete transactions, convenience, ease of use, and saving time (Alreck and Settle, 2002; Bateson, 1985; Berry et al., 2002). The potential benefits from utilizing a self-service have encouraged providers to remove contact with customers to technology-based encounters in order to increase efficiency and add consistency to service delivery (Dabholkar, 1996). TAM suggests that the attitude, intention to use service and actual use of a technology-based system are based on the perceived usefulness and perceived ease of use (Davis, 1989; Wu and Chen, 2017). Perceived usefulness has been defined as "the degree to which a person believes that using a particular system would enhance his or her job performance", while perceived ease of use has been defined as "the degree to which a person believes that using a particular system would be free of effort" (Davis, 1989, p. 320). TAM is focused more on technology, and is claimed to be different from previous measurements as it provides a valid measurement scale to predict user acceptance of information technology (IT).

\section{Empirical Review}

Early studies on self-service showed that the enhanced service quality and lesser costs resulted in the rapid adoption of self-service by customers of various services like banking (Mukerjee, 2020; Dabholkar, 1996). The customers' readiness to adopt self-service, coupled with the growing penetration of internet-enabled mobile devices, like smartphones, has prompted many service providers to make self-service usage mandatory for customers (Yang and Lee, 2016; Reinders et al., 2015). While a lot of the literature on self-service is focused on adoption and attitude towards selfservice technology, there is a lack of research pertaining to the consequences of self-service usage, which is an important line of enquiry (Robertson et al., 2016). Studies on the consequences of selfservice usage have focused on service quality (Jun and Palacios, 2016), customer relationship and loyalty (Nijssen et al., 2016), customer satisfaction and trust (Robertson et al., 2016), brand engagement (Khan et al., 2016), and service failure and recovery (Collier et al., 2017). Other studies have mentioned that customers feel more empowered and show increased participation (Djelassi et al., 2018). Customers share their opinions and recommendations based on self-service usage, and these are taken seriously by others (Singh et al., 2020). With respect to self-service, perceived useful- 
ness and perceived ease of use shape the behavioral intentions of customers (Bailey et al., 2017; Dwivedi et al., 2019).

Self-service has a significant impact on the efficiency of the overall quality and value and loyalty intentions (Dwivedi et al., 2019; Parasuraman et al., 2005). Changes in customer attitude and behavior are more important marketing objective that reflect basic psychological influences and have been a subject of intensive research for decades (Djelassi et al., 2018). Through experience and learning, people acquire beliefs and attitudes (Dwivedi et al., 2019). People believe that attributes and benefits of the product or brand influence their buying decision (Singh et al., 2020). An attitude is a person' enduring favorable or unfavorable evaluation, emotional feeling, and action tendencies toward some object or idea (Kotler and Keller, 2012). Behavioral intentions include loyalty, tendency to switch, willingness to pay more, external responses and internal responses (Wu and Chen, 2017). The focus of this study is similar to the loyalty behavior perspectives, including recommendations to others or praising self-service; intent to purchase is assumed to be higher according to the customer value of the self-service, leading to more positive behavioral intentions.

Convenience: Self-services offered by service providers have made it easy and convenient for customers to search and buy more products (Kumar and Kashyap, 2018). The role of perceived usefulness and perceived ease of use has been to offer enhanced convenience to customers and improve the self-efficacy with respect to the use of self-service (Ozturk et al., 2016). The convenience of a service refers to the time and effort required by customers to purchase or use the service (Alreck and Settle, 2002; Bateson, 1985; Berry et al., 2002). Furthermore, Brown (1989) believed that convenience includes five dimensions: time, place, acquisition, use, and execution. The time and place dimensions refer to the service provided is convenient for customers (Djelassi et al., 2018). The acquisition dimension refers to the financial or other channels provided by the enterprise to facilitate customers to purchase their services. The use dimension refers to the service that makes customers feel comfortable to use the degree of convenience. The execution dimension refers to the convenience of choosing to do it by yourself or by others. Berry et al. (2002) believed that any convenience that can reduce customer shopping time and energy can be regarded as the category of service convenience. In the consumer process, time of use is often regarded as an investment. The convenience of selfservices can provide more classes to customers to reduce customer worries and business costs effectively (Conningham et al., 2008), then it can be higher customer value. According to resource matching theory, customer should allocate matching cognitive resource to the task, if the self-service is too hard for customer to access, the task will need more cognitive resource (Anand and Sternthal, 1990). On the basis of the aforementioned arguments, the following hypothesis is proposed: 
$\mathrm{H}_{1}$ : Convenience provided by self-service will positively influence customer value.

Economy: Economy refers to the degree of customers' consumption behavior that can save money (Lovelock and Young, 1979). Price discounts or promotions that can increase customer economic value and therefore increase customers' purchases (Chen et al., 2018; Bonini and Rumiate, 2002). Zeithaml et al. (2009) think customers must give up or sacrifice when they obtain a certain product or service. Conningham et al. (2008) believed that money saving is one of the main factors for customers to use self-service. Service providers often use financial links such as promotion and price reduction to improve the economics of customers' purchases (Chen and Wang, 2016), which in turn positively affect customers' perception of value (Bailey et al., 2017; Chiu et al., 2005). Past studies have shown that customers do not always remember the actual price of a product or service, so they usually encode the actual price in a way that is more meaningful to them and convert it into the concept of "expensive" or "cheap". The price method can facilitate memory and accelerate value judgment. Self-service can usually save the cost of personnel service and provide a lower price than the personnel service model (Chen et al, 2018; Chen and Wang, 2016), so it can improve customer value. On the basis of the aforementioned arguments, the following hypothesis is proposed:

$\mathrm{H}_{2}$ : Economy provided by self-service will positively influence customer value.

Security: Security means that when customers purchase products or services, they pay special attention to the security of the transaction environment to ensure their own rights and interests (Estrella-Ramon, 2017). If customers purchase products or services through the internet, they often use credit card transactions, which may involve the unauthorized acquisition and disclosure of personal data or the risk of personal data being hacked (Mukerjee, 2020). Szymanski and Hise (2000) showed the cognitive risk of the purchase situation has a great influence on customers' shopping decision. The provision of online transaction security has a significant positive impact on customers' value perception (Mukerjee, 2020; Szymanski and Hise, 2000). Customers often prioritize product safetyrelated information provided by a company (Hurley and Ragothaman, 2002). The security of trading venues and transactions themselves is very important for customers (Dabholkar, 1996). Self-service methods require customers to operate equipment or engage in self-service by themselves (Mukerjee, 2020; Estrella-Ramon, 2017). Because customer needs secure environment to make transections, we propose that secure personnel service model can improve the customer value. On the basis of the aforementioned arguments, the following hypothesis is proposed:

$\mathrm{H}_{3}$ : Security provided by self-service will positively influence customer value. 
Reduced Complexity: Kotler and Keller (2012) believed that complexity refers to the relative difficulty of using or understanding a new product. As long as the complexity of the new product is lower than original product, customers will be more inclined to accept the new product. Conversely, higher the complexity of innovative products, less likely it is to be adopted by customers. In a self-service study based on TAM, it was found that ease of use (low complexity) and fun are very important variables (Wu and Chen, 2017). When customers are crowded and may have to wait for a long time, enterprises should emphasize that using self-service is "easy to use" and "pleasant" (Dabholkar and Bagozzi, 2002). In another study on customer trials of self-service, people also listed "complexity" as a prevariable for innovation adoption (Meuter et al., 2003). When the new self-service provided by enterprise is difficult to operate and understand, customers' willingness to use it will be reduced (Meuter et al., 2003). Shamdasani et al. (2008) also listed work complexity as one of the influencing factors for customers to use self-service. Self-service usually saves the time of personnel service and provides a lower price as compared to the personnel service (Chen et al, 2018; Chen and Wang, 2016). Consequently, we propose that the reduced complexity of self-service can improve customer value. On the basis of the aforementioned arguments, the following hypothesis is proposed:

$\mathrm{H}_{4}$ : Reduced complexity provided by self-service will positively influence customer value.

Customer Value: Value includes four dimensions: acquisition, transaction, in-use, and redemption (Parasuraman and Grewal, 2000). Customer value is considered central to acquiring competitive advantage and to the long-term success of a company (Trivedi et al., 2018; Ma et al., 2010). Customer value has become one of the key sources of competitive advantage or success (Nasution et al., 2011; Parasuraman, 1997; Woodruff, 1997). Customer value is a subjective perception constituted by multiple factors, including quality, emotional response, monetary price, behavioral price, and prestige (Petrick, 2002). Total customer value is the monetary value of the bundle of economic, functional, and psychological benefits customers expect from a given market offering. Total customer cost is the bundle of costs customers expect to incur in evaluating, obtaining, using, and disposing of the given market offering, including monetary, time, energy, and psychic costs (Kotler and Keller, 2012). Heinonen (2004) found that time and location are even more important dimensions than outcome and process elements. The theory of customer value is becoming increasingly used in management strategy formulation as well as marketing literature in recent years (Trivedi et al., 2018). The construct of perceived value has been identified as one of the most important measures for gaining competitive edge (Parasuraman, 1997), and has been argued to be the most important indicator of behavioral intentions (Parasuraman and Grewal, 2000). Zeithaml et al. (2009) defined 
customer value as the overall assessment of the utility of merchandises based on perceptions of what is received and what is given. Customer value in an online or a self-service context directly relates to benefits that are derived from using the self-service (Mukerjee, 2020). On the basis of the aforementioned arguments, the following hypothesis is proposed:

$\mathrm{H}_{5}$ : Customer value provided by self-service will positively influence behavioral intentions.

Changes to the product/service cycle means that the value of a dynamic concept will change over time. Customer value is a subjective perception constituted by multiple factors (Petrick, 2002). Heinonen (2004) found that time and location are perceived as important value dimensions. Numerous researchers have identified value as one of the critical factors in a customer's decision-making process (Baker et al., 2002; Parasuraman and Grewal, 2000; Grewal et al., 1998). Further, we propose the mediator effects offered by customer value between the relationship of self-service and behavioral intentions, the following hypotheses are proposed:

$\mathrm{H}_{6}$ : Customer value will positively mediate the relationship between convenience and behavioral intentions.

$\mathrm{H}_{7}$ : Customer value will positively mediate the relationship between economy and behavioral intentions.

$\mathrm{H}_{8}$ : Customer value will positively mediate the relationship between security and behavioral intentions.

$\mathrm{H}_{9}$ : Customer value will positively mediate the relationship between reduced complexity and behavioral intentions.

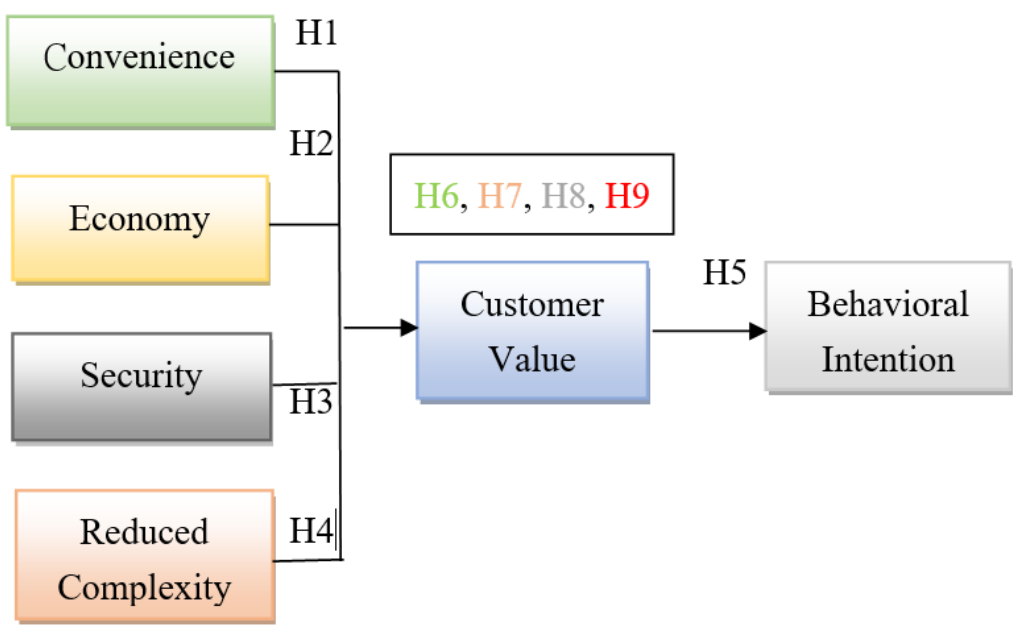

Source: Author's Presentation

Figure 1. Conceptual Framework 
The conceptual framework is given in Figure 1 above. Kotler used a stimulus-response model to analyze consumers' behavior when stimulated by marketing (black box) i.e., to examine the impact of marketing efforts on consumers' purchase decisions. A model is proposed that views the stimulus and response set in S- R ensembles as categories with dimensions that may or may not overlap (Kornblum et al., 1990). The model performs a holistic evaluation of the subject matter that affects consumers' behavioral intentions.

\section{METHODOLOGY}

\section{-Sample and Data}

A self-reported survey research design was adopted to test the hypothesized relationships. The instrument development, the summary of each construct operational definition is given in Table 1 (see Appendix-I). A questionnaire was designed using 24 items, wherein respondents rated each item on a 5-point Likert-type scale. The descriptive statistics were calculated by using SPSS 20.0. 435 questionnaires were administered to customers with self-service experience in Taiwan and a total of 350 (response rate $80.8 \%$ ) valid responses to the questionnaire were got back. In terms of gender, $60 \%$ percent of the respondents were female and 40 percent were male. The biggest group of respondents in terms of age was $40-49(38.6 \%)$. The demographic information about the samples is given in Table 2 (see Appendix-II).

\section{-Measures}

The measures for the constructs were adapted from the extant literature and adjusted to capture the context of self-service. The adapted items were shown to a group of marketing experts from the selfservice marketing domain to assess the face and content validity. Convenience and behavioral intentions were measured using three-item scale. Economy and customer value were measured with a four-item scale, while security and reduced complexity were measured using five-item scale. These items related to self-service provided an understanding of the customer's behavioral intentions.

\section{-Reliability and Validity}

The scale reliability (Cronbach's $\alpha$ ) of convenience was 0.67 , economy was 0.74 , security was 0.83 , reduced complexity was 0.73 , customer value was 0.60 and behavior intentions was 0.71 . All the scales were then subjected to confirmatory factor analysis (CFA) using SPSS 20.0 with maximum likelihood estimation method.

The scales' composite reliability (CR) and average variance extracted (AVE) for the convenience, economy, security, and reduced complexity exceeded the threshold level of 0.50 . The loadings and 
composite reliability (CR) of each of the construct was greater than 0.60 (Table 3 - Appendix-III). Thus, the constructs meet the convergent and discriminant validity criteria (Voorhees et al., 2016).

\section{-Hypotheses Testing}

The data were analyzed using structural equation modelling (SEM). The questionnaire constructed for this study was based on previous research; it was modified for the customer context. Table 3 showed each item's mean, standard deviation, and t-statistics. The descriptive statistics and Pearson correlation matrix is shown in Table 4 (see Appendix-IV).

The structural model results show that convenience, economy, security, and reduced complexity positively influences customer value, therefore, hypotheses 1 to 4 are supported. In addition, customer value positively influenced behavioral intentions. This provided support to hypothesis 5 . The mediating relationships reported to hypothesis 6 to hypothesis 9 also got support as shown in Table 5 (see Appendix-V).

\section{DISCUSSION AND CONCLUSION}

The objective of this study was to test the influence of self-service factors i.e., convenience, economy, security, and reduced complexity on customer value. Previous studies on self-service have shown that it can influence satisfaction (Meuter et al., 2000), service quality (Jun and Palacios, 2016), customer relationship and loyalty (Nijssen et al., 2016), service failure and recovery (Collier et al., 2017) etc. While behavioral intentions among self-service users have been shown as an outcome of mandated use by service providers (Reinders et al., 2015) and e-service quality (Theodosiou et al., 2019). Further, the mediating role of customer value between the relationship of self-service factors (convenience, economy, security and reduced complexity) and customer behavioral intentions has not been studied previously. The current study has made an attempt to offer new empirical evidence on the consequences of self-service factors i.e., convenience, economy, security, and reduced complexity.

The research found that convenience, economy, security, and reduced complexity are positively and significantly related to customer value. These effects show that in the self-service situation, customer value plays an important role in enhancing customers' behavioral intentions. In other words, this study found that the self-service scenario, the convenience, economy, security, and reduced complexity have a direct impact on behavioral intentions and in direct impact via customer value. This study examined the mediator effect of customer value on the relationship between self-service factors and behavioral intentions. The research not only provides insights into the study of self-service and but also will help practitioners identifying self-service influencing factors (and their relative importance). 


\section{IMPLICATIONS}

The current study has shown that factors influencing self-service i.e., convenience, economy, security, and reduced complexity have a direct impact on customer value and customer behavioral intentions. In addition, customer value partially mediates the aforementioned relationships. Managers can foster convenience through improvements in self-service, with particular focus on enhancing the perceived usefulness and perceived ease of use. The customers' journey while using self-service can be tracked by firms, and based on the analysis of customer experiences, the systems can be made more useful and easier to use (Akesson et al., 2014).

\section{LIMITATIONS AND FUTURE DIRECTIONS}

The measured subjects of this research were general consumers. Because the sample was not obtained by using random sampling, some research limitations may affect the validity and generalizability of the research results. This research examined the direct impact of four factors influencing self-service by tapping general consumers. It is recommended that subsequent related researchers may investigate different industries offering self-service. Although external validity may be limited, this study can be used as comparative research with future research studies on self-service.

\section{REFERENCES}

Abdullah, F. \& Ward, R. (2016). Developing a general extended technology acceptance model for E-learning (GETAMEL) by analyzing commonly used external factors. Computers in Human Behavior, 56, 238-256.

Alreck, P. L., \& Settle, R. B. (2002). The hurried consumer: Time-saving perceptions of Internet and catalogue shopping. Journal of Database Management, 10, 25-35.

Anand, P., \& Sternthal, B. (1990). Ease of message processing as a moderator of repetition effects in advertising. Journal of Marketing Research, 27(3): 345-53.

Bailey, A.A., Pentina, I., Mishra, A. S., \& Mimoun, M.S.B. (2017). Mobile payments adoption by US consumers: An extended TAM. International Journal of Retail and Distribution Management, 45(6): 626-640.

Baker, J., Parasuraman, A., Grewal, D., \& Voss, G. B. (2002). The influence of multiple store environment cues on perceived merchandise value and patronage intentions. Journal of Marketing, 66(2): 120-141.

Baron, R. M. \& Kenny, D. A. (1986). The Moderator-mediator variable distinction in social psychological research. Journal of Personality and Social Psychology, 51(6): 1173-1182.

Bateson, J.E.G. (1985). Self-service consumer: An exploratory study. Journal of Retailing, 61, 49-76.

Berry, L.L., Seiders, K., \& Grewal, D. (2002). Understanding service convenience. Journal of Marketing, 66, 1-17.

Bonini, N., \& Rumiati, R. (2002). Acceptance of a price discount: The role of the semantic relatedness between Purchases and the Comparative Price Format. Journal of Behavioral Decision Making, 15, 203-220.

Brown, L. G. (1989). Convenience in services marketing. Journal of Services Marketing, 4, 53-59.

Chen, C., \& Wang, J. (2016). Customer participation, value co-creation and customer loyalty- A case of airline online check-in system. Computers in Human Behavior, 62, 346-352.

Chen, Y., Yu, J., Yang, S., \& Wei, J. (2018). Consumer's intention to use self-service parcel delivery service in online retailing: an empirical study. Internet Research, 28(2), 500-519.

Chiu, H. C., Hsieh, Y. L., \& Lee, M. (2005). Relationship marketing and consumer switching behavior. Journal of Business Research, 58(12): 1681-1689.

Chiu, Chui-Yu, Chen, S., \& Chen, C. L. (2017). An integrated perspective of TOE framework and innovation diffusion in broadband mobile applications adoption by enterprises. International Journal of Management, Economics and Social Sciences, 6(1): 14-39.

Collier, J. E., Breazeale, M., \& White, A. (2017). Giving back the "self" in self-service: customer preferences in self-service failure recovery. Journal of Services Marketing, 31(6): 604-617. 
Collier, J. E., \& Sherrell, D. L. (2010). Examining the influence of control and convenience in a self-service setting. Journal of the Academy of Marketing Science, 38(4): 490-509.

Conningham, L. F., Young, C. E., \& Gerlach, J. H. (2008). Consumer views of self-service technologies. The Service Industries Journal, 6(28): 719-732.

Dabholkar, P. A. (1996). Consumer evaluations of new technology-based self-service options: An investigation of alternative models of service quality. International Journal of Research in Marketing, 13(1): 29-51.

Dabholkar, P. A., \& Bagozzi, R. P. (2002). An attitudinal model of technology-based self-service: Moderating effects of consumer traits and situational factors. Journal of the Academy of Marketing Science, 30(3): 184-201.

Davis, F. D. (1989). Perceived usefulness, perceived ease of use, and user acceptance of information technology. MIS Quarterly, 13(3): 319-340.

Djelassi, S., Diallo, M. F., \& Zielke, S. (2018). How self-service technology experience evaluation affects waiting time and customer satisfaction? A moderated mediation model. Decision Support Systems, 111, 38-47.

Dwivedi, Y. K., Rana, N. P., Jeyaraj, A., Clement, M., \& Williams, M. D. (2019). Re-examining the unified theory of acceptance and use of technology (UTAUT): Towards a revised theoretical model. Information Systems Frontiers, 21 (3): 719-734.

Estrella-Ramon, A. (2017). Explaining customers' financial service choice with loyalty and cross-buying behavior. Journal of Services Marketing, 31(6): 539-555.

Giebelhausen, M., Robinson, S. G., Sirianni, N. J., \& Brady, M. K. (2014). Touch versus tech: when technology functions as a barrier or a benefit to service encounters. Journal of Marketing, 78(4): 113-124.

Globerson, S., \& Maggard, M. J. (1991). A conceptual model of self-service. International Journal of Operations and Production Management, 11(4): 33-43.

Grewal, D., Monroe, K. B., \& Krishnan, R. (1998). The effects of price-comparison advertising on buyers' perceptions of acquisition value, transaction value, and behavioral intentions. Journal of Marketing, 62(2): 46-59.

Heinonen, K. (2004). Reconceptualizing customer perceived value: the value of time and place. Managing Service Quality: An International Journal, 14(2/3): 205-215.

Hurley, N., \& Ragothaman, S. (2002). An empirical analysis of the security aspects of E-business payment systems. South Dakota Business Review Vermilion, 60(4): 1-7.

Jun, M., \& Palacios, S. (2016). Examining the key dimensions of mobile banking service quality: An exploratory study. International Journal of Bank Marketing, 34(3): 307-326.

Khan, I., Rahman, Z., \& Fatma, M. (2016). The role of customer brand engagement and brand experience in online banking. International Journal of Bank Marketing, 34(7): 1025-1041.

Kimes, S. E., \& Collier, J. E. (2015). How customers view self-service technologies. MIT Sloan Management Review, 57(1): 2526.

Kotler, P., \& Keller, K. L. (2012). Marketing Management. $14^{\text {th }}$ Edition, NJ: Prentice Hall.

Kornblum, S., Hasbroucq, T., \& Osman, A. (1990). Dimensional overlap: Cognitive basis for stimulus-response compatibility A model and taxonomy. Psychological Review, 97(2): 253-270.

Kumar, A., \& Kashyap, A. K. (2018). Leveraging utilitarian perspective of online shopping to motivate online shoppers. International Journal of Retail and Distribution Management, 46(3): 247-263.

Lovelock, C., \& Young, R. (1979). Look to consumers to increase productivity. Harvard Business Review, 57(May/June): 168178.

Ma, Y., Ding, J., \& Hong, W. (2010). Delivering customer value based on service process: The example of Tesco.com. International Business Research, 3(2): 131-135

Meuter, M. L., Ostrom, A. L., Bitner, M. J., \& Bitner, M. J. (2000). Self-service technologies: Understanding customer satisfaction with technology-based service encounters. Journal of Marketing, 64, , 50-64.

Meuter, M. L., Ostrom, A. L., Bitner, M. J., \& Roundtree, R. (2003). The influence of technology anxiety on consumer use and experiences and experience with self-service technologies. Journal of Business Research, 56, 889-906.

Mukerjee, K. (2020). Impact of self-service technologies in retail banking on cross-buying and word-of-mouth. International Journal of Retail and Distribution Management, 48(5): 485-500.

Nasution, H. N., Mavondo, F. T., Matanda, M. J., \& Olyndubisi, N. (2011). Entrepreneurship: Its relationship with market orientation and learning orientation and as antecedents to innovation and customer value. Industrial Marketing Management, $40,336-345$

Nijssen, E. J., Schepers, J. J. L., \& Belanche, D. (2016). Why did they do it? How customers' self-service technology introduction attributions affect the customer-provider relationship. Journal of Service Management, 27(3): 276-298.

Ozturk, A. B., Nusair, K., Okumus, F., \&Hua, N. (2016). The role of utilitarian and hedonic values on users' continued usage intention in a mobile hotel booking environment. International Journal of Hospitality Management, 57, 106-115.

Parasuraman, A. (1997). Reflections on Gaining Competitive Advantage through Customer Value. Academy of Marketing Science, Journal, 25(2): 154-161.

Parasuraman, A., \& Grewal, D. (2000). The impact of technology on the quality-value-loyalty chain: a research agenda. Journal of the Academy of Marketing Science, 28(1): 168-174.

Parasuraman, A., Zeithaml, V. A., \& Malhotra, A. (2005). E-S-QUAL A multiple-item scale for assessing electronic service quality. Journal of Service Research, 7(3): 213-233.

Petrick, J. F. (2002). Development of a multi-dimensional, scale for measuring the perceived value of a service. Journal of Leisure Research, 34, 119-134.

Reinders, M. J., Frambach, R., \& Kleijnen, M. (2015). Mandatory use of technology-based self-service: does expertise help or 


\section{International Journal of Management, Economics and Social Sciences}

hurt. European Journal of Marketing, 49(1/2): 190-211.

Robertson, N., McDonald, H., Leckie, C., \& McQuilken, L. (2016). Examining customer evaluations across different self-service technologies. Journal of Services Marketing, 30(1): 88-102.

Shamdasani, P., Mukherjee, A., \& Malhotra, N. (2008). Antecedents and consequences of service quality in consumer evaluation of self-service internet technologies. Service Industries Journal, 28(1): 117-138.

Singh, N., Sinha, N., \& Lie'bana-Cabanillas, F. J. (2020). Determining factors in the adoption and recommendation of mobile wallet services in India: Analysis of the effect of innovativeness, stress to use and social influence. International Journal of Information Management, 50, 191-205.

Szymanski, D. M., \& Hise, R. T. (2000). E-satisfaction: An initial examination. Journal of Retailing, 76(3): 309-322.

Theodosiou, M., E. S., Katsikea, S., \& Makri, K. (2019). A comparison of formative versus reflective approaches for the measurement of electronic service quality. Journal of Interactive Marketing, 47, 53-67.

Trivedi, P., Trivedi, K., \& Goswami, V. (2018). Sustainable marketing strategies: Creating business value by meeting consumer expectation. International Journal of Management, Economics and Social Sciences, 7(2): 186-205.

Voorhees, C. M., Brady, M. K., Calantone, R., \& Ramirez, E. (2016). Discriminant validity testing in marketing: an analysis, causes for concern, and proposed remedies. Journal of the Academy of Marketing Science, 44(1): 119-134.

Wirtz, J., \& Zeithaml, V. (2018). Cost-effective service excellence. Journal of the Academy of Marketing Science, 46(1): 59-80.

Woodruff, R. (1997). Customer value: The next source for competitive advantage. Journal of the Academy of Marketing Science, 25(2): 139-153.

Wu, B., \& Chen, X. (2017). Continuance intention to use MOOCs: integrating the technology acceptance model (TAM) and task technology fit (TTF) model. Computers in Human Behavior, 67, 221-232.

Yang, D. J., \& Lee, C. W. (2016). In-store promotional mix and the effects on female consumer buying decisions in relation to cosmetic products. International Journal of Management, Economics and Social Sciences, 5(2): 35-56.

ZeithamI, V. A., Bitner, M. J., \& Gremler, D. D. (2009). Service Marketing. $5^{\text {th }}$ Edition. McGraw-Hill. 


\begin{tabular}{|c|c|c|}
\hline Construct & Operation Definition & Reference Sources \\
\hline Convenience & $\begin{array}{l}\text { When customers use self-service, the } \\
\text { service can save customers time and/or } \\
\text { effort. }\end{array}$ & $\begin{array}{l}\text { Alreck and Settle, 2002; Berry et al., } \\
2002\end{array}$ \\
\hline Economy & $\begin{array}{l}\text { The price for customers to use self- } \\
\text { service is cheaper than non-self-service. } \\
\text { (can save more money) }\end{array}$ & $\begin{array}{l}\text { Lovelock and Young, 1979; Bonini } \\
\text { and Rumiati, } 2002\end{array}$ \\
\hline Security & $\begin{array}{l}\text { Self-service provided a safe transaction } \\
\text { environment and made customers easy } \\
\text { to use. }\end{array}$ & $\begin{array}{l}\text { Dabholkar et al., 2002; Parasuraman } \\
\text { et al., } 1985\end{array}$ \\
\hline Reduced Complexity & $\begin{array}{l}\text { The use of self-service is simple, clear } \\
\text { and easy to understand or complicated, } \\
\text { vague and difficult. }\end{array}$ & Rogers, 1985; Kotler and Keller, 2012 \\
\hline Customer Value & $\begin{array}{l}\text { The overall evaluation of the benefits } \\
\text { and costs by using self-service. }\end{array}$ & $\begin{array}{l}\text { Zeithaml et al., 2009; Kotler and } \\
\text { Keller, } 2012\end{array}$ \\
\hline Behavioral Intentions & $\begin{array}{l}\text { The possibility that customers are } \\
\text { willing to repurchases behavior. }\end{array}$ & Zeithaml et al., 2009 \\
\hline
\end{tabular}

Table 1. Operation Definitions of Constructs 


\begin{tabular}{|c|c|c|}
\hline & $\mathbf{N}$ & $\%$ \\
\hline \multicolumn{3}{|l|}{ Gender } \\
\hline Male & 140 & $40 \%$ \\
\hline Female & 210 & $60 \%$ \\
\hline \multicolumn{3}{|l|}{ Age (years) } \\
\hline $20-29$ & 90 & $25.7 \%$ \\
\hline $30-39$ & 122 & $34.9 \%$ \\
\hline $40-49$ & 135 & $38.6 \%$ \\
\hline$>50$ & 3 & $0.80 \%$ \\
\hline \multicolumn{3}{|l|}{ Education } \\
\hline High School & 35 & $10.0 \%$ \\
\hline Undergraduate & 241 & $68.9 \%$ \\
\hline Graduate & 74 & $21.1 \%$ \\
\hline \multicolumn{3}{|l|}{ Annual income } \\
\hline Less than NT\$10,000 & 30 & $08.6 \%$ \\
\hline Between NT\$10,000-30,000 & 82 & $23.4 \%$ \\
\hline Between NT\$30,001-50,000 & 122 & $34.9 \%$ \\
\hline Between NT\$50,001-75,000 & 80 & $22.9 \%$ \\
\hline More than NT\$75,001 & 36 & $10.2 \%$ \\
\hline
\end{tabular}

Table 2. Demographic Profiles of Respondents 
Appendix-III

\begin{tabular}{cccccc}
\hline & Items & Loadings & Cronbach's $\boldsymbol{\alpha}$ & CR & AVE \\
\hline Convenience & 3 & 0.609 & 0.671 & 0.676 & 0.575 \\
Economy & 4 & 0.680 & 0.744 & 0.747 & 0.550 \\
Security & 5 & 0.768 & 0.832 & 0.838 & 0.654 \\
Reduced Complexity & 5 & 0.685 & 0.730 & 0.731 & 0.675 \\
Customer Value & 4 & 0.609 & 0.604 & 0.655 & 0.528 \\
Behavioral Intention & 3 & 0.985 & 0.711 & 0.712 & 0.558 \\
\hline
\end{tabular}

Source: Author's Computation

Table 3. Reliability and Validity 


\begin{tabular}{|c|c|c|c|c|c|c|c|}
\hline & Mean & SD & 1 & 2 & 3 & 4 & 5 \\
\hline 1.Convenience & 4.33 & 0.52 & & & & & \\
\hline 2.Economy & 3.28 & 0.74 & $0.10^{*}$ & & & & \\
\hline 3.Security & 3.70 & 0.66 & 0.08 & $0.23^{* *}$ & & & \\
\hline 4.R. Complexity & 4.21 & 0.40 & $0.38^{* *}$ & $0.13^{* *}$ & $0.38^{* *}$ & & \\
\hline 5.Customer Value & 4.15 & 0.41 & $0.27^{* *}$ & $0.25^{* *}$ & $0.28^{* *}$ & $0.35^{* *}$ & \\
\hline 6. Behavioral Intention & 4.34 & 0.46 & $0.56^{* *}$ & $0.17^{* *}$ & $0.31^{\text {** }}$ & $0.55^{* *}$ & $0.42^{* *}$ \\
\hline
\end{tabular}

Source: Author's Computation

Notes: $* * p<0.01 ;{ }^{*} p<0.05$

Table 4. Descriptive Statistics and Correlation Matrix 
Appendix-IV

\begin{tabular}{llll}
\hline Paths & $\beta$-value & $\boldsymbol{p}$-value & Results \\
\hline Direct relationships / direct effects & & & \\
H1 Convenience $\rightarrow$ Customer value & 0.274 & 0.000 & Supported \\
H2 $\quad$ Economy $\rightarrow$ Customer value & 0.250 & 0.000 & Supported \\
H3 Security $\rightarrow$ Customer value & 0.285 & 0.000 & Supported \\
H4 R.Complexity $\rightarrow$ Customer value & 0.350 & 0.000 & Supported \\
H5 Customer value $\rightarrow$ Behavioral Intention & 0.428 & 0.000 & Supported \\
\hline Indirect relationships / mediating effects & & & \\
H6 Convenience $\rightarrow$ Behavioral Intention & 0.483 & 0.000 & Supported-partial mediation \\
Convenience $\rightarrow$ Customer value & 0.565 & 0.000 & \\
H7 Economy $\rightarrow$ Behavioral Intention & 0.070 & 0.000 & Supported-full mediation \\
Economy $\rightarrow$ Customer value & 0.172 & 0.000 & \\
H8 Security $\rightarrow$ Behavioral Intention & 0.231 & 0.000 & Supported-partial mediation \\
Security $\rightarrow$ Customer value & 0.318 & 0.000 & \\
H9 R.Complexity $\rightarrow$ Behavioral Intention & 0.468 & 0.000 & Supported-partial mediation \\
R.Complexity $\rightarrow$ Customer value & 0.557 & 0.000 & \\
\hline$\quad$ Sourc: Author's Computation & & &
\end{tabular}

Source: Author's Computation

Table 5. Summary of Hypothesized Relationships 